\title{
CD14 expression and soluble CD14 after segmental allergen provocation in atopic asthma
}

\author{
J.C. Virchow Jr*, P. Julius*, H. Matthys*, C. Kroegel+, W. Luttmann*
}

CD14 expression and soluble CD14 after segmental allergen provocation in atopic asthma J.C. Virchow Jr, P. Julius, H. Matthys, C. Kroegel, W. Luttmann. CERS Journals Ltd 1998. ABSTRACT: Allergic asthma is associated with the recruitment of activated inflammatory cells after allergen challenge. Surface expression of CD14 has been proposed as a marker of cell activation and differentiation.

We therefore measured CD14 expression on activated macrophages and granulocytes as well as soluble CD14 (sCD14) concentrations in peripheral blood and bronchoalveolar lavage (BAL) following segmental allergen provocation (SAP) with individually standardized doses of allergen in eight patients with allergic asthma. Two segments of the right lung were challenged with allergen. Two segments of the left lung, into which saline was instilled, served as controls. CD14 expression on macrophages and granulocytes was determined by flow-cytometry and concentrations of interleukins and sCD14 were analysed by enzyme-linked immunosorbent assay (ELISA) $10 \mathrm{~min}$ and $18 \mathrm{~h}$ after challenge.

Soluble CD14 concentrations remained unchanged in BAL fluid after saline challenge and $10 \mathrm{~min}$ after SAP, but increased significantly $18 \mathrm{~h}$ after SAP. Although macrophage numbers increased $18 \mathrm{~h}$ after SAP, CD14 expression on these cells did not change. Unlike macrophages, granulocyte numbers correlated with sCD14 levels $18 \mathrm{~h}$ after SAP while their CD14 expression decreased significantly. Furthermore, sCD14 correlated with interleukin (IL)-13 concentrations $18 \mathrm{~h}$ after SAP.

An increase in soluble CD14 can be observed $18 \mathrm{~h}$ but not 10 min after segmental allergen provocation suggesting local release of this surface antigen. Our findings imply that CD14-mediated cell activation following segmental allergen provocation could play a role in asthmatic inflammation.

Eur Respir J 1998; 11: 317-323.
*Abteilung für Pneumologie, Robert-KochKlinik, Medizinische Universitätsklinik Freiburg, Freiburg, Germany. ${ }^{+}$Funktionsbereich Pneumolgie, Medizinische Klinik Abteilung IV, Friedrich Schiller Universität, Jena, Germany.

Correspondence: J.C. Virchow Jr

Abteilung für Pneumologie

Robert-Koch-Klinik

Medizinische Universitätsklinik Freiburg Hugstetterstrasse 55

D-79106 Freiburg

Germany

Fax: 497612703704

Keywords: Allergen provocation

asthma

CD14

soluble CD14

macrophages

Received: May 71997

Accepted after revision October 251997

This study was supported by the State Baden-Württemburg, Kernforschungszentrum Karlsruhe, PUG Germany (PUG L94/007).
CD14, a $53 \mathrm{kDa}$ surface glycoprotein, has been described as a myelomonocytic differentiation antigen and activation marker on monocytes, macrophages, granulocytes and B-lymphocytes $[1,2]$. CD14 serves as a receptor for lipopolysaccharide (LPS) [3] and binding of LPS to CD14 induces macrophage activation with release of cytokines such as interleukin (IL)-6, IL-8 and tumour necrosis factor $(\mathrm{TNF}-\alpha)[2,4]$. In vitro CD14 expression on macrophages and monocytes is enhanced by TNF- $\alpha$, IL- 1 , IL- 6 [2] and downregulated by IL-4 [5, 6], while results for interferon (IFN)- $\gamma[7,8]$ are equivocal. Although CD14 expression on alveolar macrophages has been described in normal as well as diseased lung [9], the in vivo regulation of CD14 remains unclear.

In vitro, $\mathrm{CD} 14$ is constitutively released from monocytic cell cultures as soluble CD14 (sCD14) [10, 11]. Its levels increase concomitantly with the cell-surface expression of CD14 [2]. Shedding of CD14 is decreased by IL-4 $[10,12]$. IL-13, a cytokine with similar features to IL-4 has been shown to downregulate $\mathrm{SCD} 14$ release on a transcriptional level [13]. A reduction of sCD14 levels by

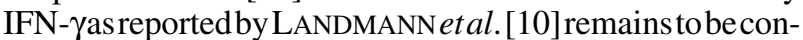
firmed [12]. Addition of LPS and TNF- $\alpha$ to in vitro cultures causes a dose-dependent increase in sCD14 [12] while sCD14 potentiates LPS-induced release of TNF- $\alpha$ and IL-6 from monocytic cells [14].

In vivo elevated levels of sCD14 have been reported in bronchoalveolar lavage (BAL) fluid in pulmonary diseases such as tuberculosis, sarcoidosis, allergic alveolitis and idiopathic pulmonary fibrosis [2, 9, 15-18]. Furthermore, DUBIN et al. [19] have recently shown an increase in LPS binding protein and sCD14 $24 \mathrm{~h}$ following segmental allergen challenge. Several of the cytokines implicated in the regulation of CD14, such as TNF- $\alpha$ and IL- 6 , are released following CD14-mediated activation of macrophages and have been found in elevated concentrations following segmental allergen provocation (SAP) in allergic asthma [20]. Since activation of macrophages is a feature of asthma [21], we examined CD14 expression on alveolar macrophages and granu-locytes as well as sCD14 concentrations in blood and BAL-fluid in sensitized subjects using the model of SAP. Furthermore, concentrations of IL-4, IL-13, and IL-5 which have been implicated in the differential regulation of allergic reactions as well as TNF- $\alpha$ and IFN- $\gamma$ were measured to elucidate a possible role for these cytokines in the regulation of CD14 expression and $\mathrm{sCD} 14$ release in vivo. 


\section{Materials and methods}

\section{Patients}

Eight mild, allergic asthmatics, six males, and two females, mean age $27 \pm 5$ yrs with a duration of asthma of more than 2 yrs (mean duration $9.9 \pm 4.6$ yrs) were studied. All patients suffered from allergic asthma as defined elsewhere [22]. There was a history of intermittent wheeze, chest tightness, cough and sputum production, either spontaneously or exercise-induced, and a bronchial hyperreactivity as determined by a modified bronchoprovocation test with carbachol [23]. All patients had previously been diagnosed as asthmatic by an independent physician, and all had a positive skin-prick test to either birch pollen $(n=2)$, rye pollen $(n=4)$, or house-dust mite allergen $(n=2)$ extracts (Allergopharma, Reinbek, Germany). Furthermore, they all had elevated total immunoglobulin (Ig)E levels $\left(687.6 \pm 868.7 \mathrm{kU} \cdot \mathrm{L}^{-1}\right)$ as well as specific IgE levels of $>0.35 \mathrm{kU} \cdot \mathrm{L}^{-1}\left(32.1 \pm 33.6 \mathrm{kU} \cdot \mathrm{L}^{-1}\right)$ (Kabi Pharmacia CAP System, Uppsala, Sweden) to their respective allergen as well as a history of reversible bronchoconstriction after inhalation of these particular allergens. Only one patient had a low total IgE level but a clear history of allergen induced bronchoconstriction and an elevated specific IgE concentration. There was no history or clinical evidence suggesting a respiratory tract infection prior to or at the time of the segmental allergen challenge in any of the patients. All patients were nonsmokers. Baseline forced expiratory volume in one second (FEV1) expressed as a

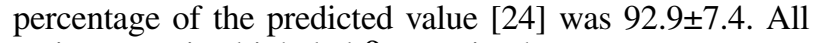
patients received inhaled $\beta_{2}$-agonist therapy on an as needed basis. Cromoglycate $(n=3)$ and inhaled corticosteroids $(n=2)$ were withheld for 7 days prior to entry into the study. Further patient characteristics are listed in table 1. All patients gave their written informed consent. The study protocol was approved by the Ethics Committee of the University of Freiburg.

\section{Inhaled allergen provocation}

Prior to the segmental allergen challenge, all patients underwent an inhaled allergen challenge to establish dual bronchial reactions and to determine the individual provocative dose of allergen causing a $20 \%$ fall in FEV1 (PD20) for the respective allergen. All allergen preparations used in this study tested negative for LPS in the limulus amoebocyte lysate assay [25]. Breathing at tidal volume, patients inhaled $2 \mathrm{~mL}$ saline from a jet nebulizer (Pari Boy; Pari Werke, Starnberg, Germany) which generated aerosol only during inspiration. The number of breaths required to inhale $2 \mathrm{~mL}$ saline was counted individually. Subsequently, each patient was challenged, starting with a $1: 10,000$ dilution (corresponding to 1 milli biological units $(\mathrm{mBU}) \cdot \mathrm{mL}^{-1}$ ) of the original allergen solution (Abello, Bornheim, Germany) from which a total of 10 tidal volume manoeuvres were inhaled. FEV1 was recorded after 5, 10 and $20 \mathrm{~min}$. The allergen concentration was then repeatedly increased tenfold until a $20 \%$ decrease in FEV1 was observed. FEV1 was recorded at $30 \mathrm{~min}$, $60 \mathrm{~min}$ and then hourly for $9 \mathrm{~h}$. Patients were included in the study, if a second decline in FEV 1 of $>15 \%$ from baseline consistent with a late asthmatic reaction was observed 5-9 $\mathrm{h}$ after allergen challenge. The individual PD20 (mBU of allergen) was derived by extrapolation of the relationship between dose of allergen inhaled and FEV 1 to the point where a decline in FEV $1>20 \%$ was recorded. A tenfold increased dose of allergen was then used for the subsequent SAP. Inhaled allergen challenge and SAP were separated by at least 3 weeks.

\section{Segmental allergen challenge}

Bronchoscopy was performed as described previously [20] using an Olympus BF 1T20D bronchoscope (Olympus, Hamburg, Germany) via the oral route. As a control, $2.5 \mathrm{~mL}$ of saline was instilled into the inferior lingular bronchus (B5 left). Furthermore, in six patients $2.5 \mathrm{~mL}$ of saline was instilled into one segment of the lower left lobe, which was lavaged after $10 \mathrm{~min}$ as described below. According to the inhaled allergen provocation, individually standardized doses of allergen (rye pollen, birch pollen or house-dust mite allergen) diluted in $2.5 \mathrm{~mL}$ saline were instilled into the medial basal segment of the right lower lobe (B7 right) and into the medial segment of the right middle lobe (B5 right). The right lower lobe bronchus was lavaged $10 \mathrm{~min}$ after endoscopic allergen deposition using aliquots of $25 \mathrm{~mL}$ which were aspirated using gentle hand suction. The patients were then extubated applying constant suction on the bronchoscope to avoid contamination of the left bronchial system.

After $18 \mathrm{~h}$, the bronchoscope was re-inserted and the left lingular bronchus, into which $2.5 \mathrm{~mL}$ diluent had already been instilled, was lavaged; subsequently, the me-

Table 1. - Patient characteristics

\begin{tabular}{|c|c|c|c|c|c|c|c|c|c|c|}
\hline Sex & $\begin{array}{l}\text { Age } \\
\text { yrs }\end{array}$ & $\begin{array}{c}\text { Duration } \\
\text { of asthma } \\
\text { yrs }\end{array}$ & $\begin{array}{c}\text { FEV1 } \\
\text { baseline } \\
\text { L }\end{array}$ & $\begin{array}{l}\text { FEV } 1 \\
\% \text { pred }\end{array}$ & $\begin{array}{l}\text { IVC } \\
\% \text { pred }\end{array}$ & $\begin{array}{c}\operatorname{IgE} \\
\mathrm{kU} \cdot \mathrm{L}^{-1}\end{array}$ & Allergen & $\begin{array}{c}\text { Specific } \\
\text { IgE } \\
\mathrm{kU} \cdot \mathrm{L}^{-1}\end{array}$ & $\begin{array}{c}\text { Allergen } \\
\text { dose } \\
\mathrm{mBu}\end{array}$ & Medication \\
\hline $\mathrm{M}$ & 26 & 13 & 4.0 & 100 & 102 & 736 & Rye & 100.0 & 575 & ICS, $\beta$ \\
\hline M & 23 & 3 & 3.7 & 82 & 94 & 173 & Rye & 26.2 & 1240 & $\mathrm{CR}, \beta$ \\
\hline M & 24 & 14 & 4.5 & 93 & 91 & 2000 & Rye & 18.7 & 1900 & $\mathrm{CR}, \beta$ \\
\hline M & 21 & 7 & 4.5 & 105 & 93 & 246 & Birch & 3.8 & 1750 & $\mathrm{CR}, \beta$ \\
\hline $\mathrm{F}$ & 29 & 12 & 2.8 & 93 & 95 & 2100 & D. pt. & 18.0 & 12630 & ICS, $\beta$ \\
\hline $\mathrm{M}$ & 25 & 9 & 3.9 & 92 & 68 & 107 & D. $f$. & 66.0 & 14600 & $\beta$ \\
\hline $\mathrm{F}$ & 38 & 5 & 2.8 & 93 & 92 & 99 & Birch & 19.6 & 8200 & $\beta$ \\
\hline M & 29 & 16 & 3.0 & 85 & 90 & 39 & Rye & 4.2 & 4500 & $\beta$ \\
\hline
\end{tabular}

FEV1: forced expiratory volume in one second; \% pred: percentage of predicted value; IVC: inspiratory vital capacity; IgE: immunoglobulin E; mBu: milli biological units; D. pt.: Dermatophagoides pteronyssinus; D. f.: Dermatophagoides farinae; ICS: inhaled corticosteroid; $\beta$ : beta-2-agonist p.r.n.; CR: cromoglycate; M: male; F: female. 
dial segment of the right middle lobe bronchus was identified and lavaged using the same technique as described above.

\section{Analysis of blood and bronchoalveolar lavage leukocyte and lymphocyte subsets}

Venous blood was drawn into sterile plastic containers containing ethylenediamine tetra-acetic acid (EDTA) (Sarstedt, Nümbrecht, Germany) prior to the first and second bronchoscopies. Peripheral blood differential cell counts were performed using an automated cell counter from the standard hospital service. Bronchoalveolar lavage (BAL) samples were filtered through a two-layer sterile gauze into sterile plastic vials (Falcon, Oxnard, USA), centrifuged at $4^{\circ} \mathrm{C}$ and $500 \times \mathrm{g}$ for $10 \mathrm{~min}$. The supernatant was removed and stored at $-70^{\circ} \mathrm{C}$. Nucleated cells were differentiated and results expressed as total number of cells per millilitre of recovered fluid. Specific binding of monoclonal antibodies to CD14 was analysed according to standard methods for triple immunofluorescence with a flow-cytometer (FACScan; Becton Dickinson, Heidelberg, Germany). Briefly, erythrocytes were lysed by adding $20 \mathrm{~mL}$ of hypotonic saline $(\mathrm{NaCl} 0.2 \%)$ to $3 \mathrm{~mL}$ blood for $30 \mathrm{~s}$. Then $20 \mu \mathrm{l}$ of either whole blood or cells from BAL were incubated in the presence of saturating concentrations of fluorescein-conjugated anti-CD14 monoclonal antibody (Dako, Hamburg, Germany) in the dark on ice for $30 \mathrm{~min}$. The cells were washed twice with phosphate buffered saline (PBS) containing 2\% foetal calf serum (FCS). Cytofluorometric analysis were performed on 10,000 cells from each sample by using laser excitation at $488 \mathrm{~nm}$. Nonspecific fluorescence was detected by incubating cells with mouse IgG of the same isotype, but with irrelevant antigen specificity. The specific mean fluorescence (SMF) for each population expressed as fluorescence intensity (FI) was determined by subtracting the nonspecific fluorescence from the mean fluorescence measured with anti-CD14 antibodies.

\section{Determination of $s C D 14, I F N-\gamma, T N F-\alpha, I L-4, I L-5$ and IL-13}

The sCD14 concentrations were measured according to the recommendations of the manufacturer (IBL, Hamburg, Germany). IL-13 was quantified using a commercially available enzyme-linked immunosorbent assay (ELISA) (Bender and Co., Vienna, Austria) according to the manufacturer's instructions. Antibody and standard cytokine for IFN- $\gamma$ quantification were kindly provided by $\mathrm{H}$. Galati (Hoffmann La Roche, Basel, Switzerland). Briefly, ELISA plates (Maxisorp, Nunc, Denmark) were coated with 5 $\mu \mathrm{g} \cdot \mathrm{mL}^{-1}$ of anti-human IFN- $\gamma$ antibody in coating buffer (0.1 $\mathrm{M} \mathrm{NaHCO}_{3}, \mathrm{pH} 8.2$ ) over $24 \mathrm{~h}$ at room temperature, washed with distilled water and saturated with $1 \%$ bovine serum albumin (BSA)/Tris ( $\mathrm{pH} 7.5$ ) for $2 \mathrm{~h}$. Standards and samples ( $200 \mu \mathrm{L}$ per well) and $50 \mu \mathrm{L}$ peroxidase- conjugated monoclonal anti-IFN- $\gamma$ antibody at a concentration of $0.3 \mu \mathrm{g} \cdot \mathrm{mL}^{-1}$ were added overnight at $4^{\circ} \mathrm{C}$. After thorough washing with distilled water $200 \mu \mathrm{L}$ tetramethylbenzidine (TMB) solution (20 mM TMB and $50 \mathrm{mM} \mathrm{H}_{2} \mathrm{O}_{2}$ dissolved in $30 \mathrm{mM}$ citrate buffer, $\mathrm{pH} 4.1$ ) was added to each well. After $15 \mathrm{~min}$ at room temperature, the reaction was stopped (100 $\mu \mathrm{L}$ of $0.1 \mathrm{M} \mathrm{H}_{2} \mathrm{SO}_{4}$ ) and ab-sorption was measured at $450 \mathrm{~nm}$. IL-4, IL-5 and TNF- $\alpha$ were assessed in BAL fluid using monoclonal anti-human cytokine antibodies (Clone: IL-4I, TRFK5, and MAb1; PharMingen, San Diego, CA, USA) as capture-antibody and biotin-conjugated monoclonal anti-human cytokine antibodies (Clone: MP4-25D2, JES1-5A10, and MAb11; PharMingen) in a concentration of $2 \mu \mathrm{g} \cdot \mathrm{mL}^{-1}$ as described previously [26]. The results were obtained from a standard curve established with human recombinant IL-4 (PBH, Hannover, Germany), IL-5 (kindly provided by H. Galati) and TNF- $\alpha$ (PharMingen). Measurements were performed in duplicate and are expressed as means from both determinations.

\section{Statistical analysis}

Results are expressed as arithmetic mean \pm SD. Differences between groups were analysed using the Wilcoxon matched pairs test. Differences with p-values of less than 0.05 were considered statistically significant. Relationships are expressed using Spearman's rank correlation.

\section{Results}

\section{Cellular composition in peripheral blood}

The total cell number in peripheral blood increased significantly $18 \mathrm{~h}$ after segmental allergen provocation $\left(8,325 \pm 2,070\right.$ cells $\left.\mu \mathrm{L}^{-1}\right)$ compared to baseline $(5,937 \pm$ 1,031 cells $\left.\mu \mathrm{L}^{-1}\right)(\mathrm{p}=0.02)$. This was accompanied by a small but statistically significant increase in the number of eosinophils $\left(254 \pm 157\right.$ cells $\mu \mathrm{L}^{-1}$ at baseline to $343 \pm$ 174 cells $\cdot \mu \mathrm{L}^{-1} 18 \mathrm{~h}$ after SAP; $\left.\mathrm{p}<0.02\right)$. There was no significant change in the relative number of neutrophils, monocytes, or eosinophils, while the relative number of lymphocytes decreased significantly from $27.7 \pm 4.5$ to $21.4 \pm 8.0 \%(\mathrm{p}=0.05)$.

\section{Cellular composition in bronchoalveolar lavage}

The total cell numbers in the segments lavaged $10 \mathrm{~min}$ after allergen challenge $\left(90.0 \pm 47.8\right.$ cells $\left.\cdot \mu \mathrm{L}^{-1}\right)$ and in the control segment lavaged $10 \mathrm{~min}$ after saline instillation $\left(107.0 \pm 101.9\right.$ cells $\left.\cdot \mu \mathrm{L}^{-1}\right)$ were similar. The total cell num-

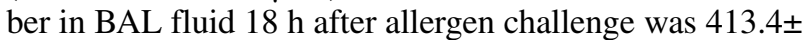
263.8 cells $\cdot \mu \mathrm{L}^{-1}$, while $260.7 \pm 201.0$ cells $\cdot \mu \mathrm{L}^{-1}$ were present in the BAL fluid $18 \mathrm{~h}$ after saline instillation, which was not statistically different. The cellular findings are shown in table 2 .

\section{CD14 expression on macrophages and granulocytes}

There was no obvious difference in the expression of CD14 on macrophages after saline or allergen challenge $(300.5 \pm 132.1$ FI $10 \mathrm{~min}$ after saline challenge; $377.1 \pm 125.2$ FI $10 \mathrm{~min}$ after SAP; $358.1 \pm 108.9$ FI $18 \mathrm{~h}$ after saline challenge; $363.1 \pm 47.0$ FI $18 \mathrm{~h}$ after SAP). In contrast, CD14 expression on granulocytes was significantly lower $18 \mathrm{~h}$ following segmental allergen provocation $(21.9 \pm 6.3 \mathrm{FI})$ as compared to segments lavaged $18 \mathrm{~h}$ after saline challenge $(56.2 \pm 32.9$ FI, $\mathrm{p}<0.02)$ (fig. 1) while CD14 expression in the control segment lavaged $10 \mathrm{~min}$ 
Table 2. - Absolute and relative numbers of cells in bronchoalveolar lavage fluid after segmental allergen provocation

\begin{tabular}{|c|c|c|c|c|}
\hline & Macrophages & Neutrophils & Eosinophils & Lymphocytes \\
\hline \multicolumn{5}{|c|}{ Absolute number cells $\mu \mathrm{L}^{-1}$} \\
\hline C 10 min & $75.4 \pm 75.6$ & $0.5 \pm 0.7$ & $3.1 \pm 5.1$ & $27.2 \pm 25.6$ \\
\hline $\mathrm{C} 18 \mathrm{~h}$ & $202.2 \pm 197.3$ & $12.4 \pm 13.9$ & $7.8 \pm 8.4$ & $29.2 \pm 17.9$ \\
\hline P 10 min & $66.7 \pm 45.4$ & $0.8 \pm 1.3$ & $2.5 \pm 3.6$ & $28.1 \pm 35.1$ \\
\hline $\mathrm{P} 18 \mathrm{~h}$ & $126.3 \pm 108.9$ & $39.5 \pm 38.2$ & $106.5 \pm 134.3$ & $68.7 \pm 46.1$ \\
\hline \multicolumn{5}{|c|}{ Relative number $\%$} \\
\hline C $10 \mathrm{~min}$ & $71.2 \pm 11.6$ & $0.7 \pm 1.0$ & $1.4 \pm 2.1$ & $26.7 \pm 10.8$ \\
\hline $\mathrm{C} 18 \mathrm{~h}$ & $69.5 \pm 13.8$ & $9.9 \pm 9.2$ & $4.6 \pm 4.9$ & $16.0 \pm 11.7$ \\
\hline P 10 min & $70.6 \pm 16.6$ & $0.6 \pm 1.0$ & $2.0 \pm 1.5$ & $26.7 \pm 16.9$ \\
\hline $\mathrm{P} 18 \mathrm{~h}$ & $39.0 \pm 23.7$ & $9.0 \pm 7.3$ & $32.6 \pm 20.9$ & $19.5 \pm 7.2$ \\
\hline
\end{tabular}

Values are presented as mean \pm SD. Saline challenged control segments were lavaged after $10 \mathrm{~min}(\mathrm{C} 10 \mathrm{~min})$ and after $18 \mathrm{~h}(\mathrm{C} 18 \mathrm{~h})$. Allergen challenged segments were lavaged $10 \mathrm{~min}$ after challenge with 10 times the provocative dose of allergen causing forced expiratory volume in one second to fall by $20 \%$ (P $10 \mathrm{~min}$ ) and $18 \mathrm{~h}$ after challenge (P $18 \mathrm{~h}$ ). Statistical comparisons are given in the text.

after saline instillation $(59.4 \pm 51.8 \mathrm{FI})$ and the segment lavaged 10 min after allergen challenge $(52.7 \pm 34.1 \mathrm{FI})$ was similar to the segment lavaged $18 \mathrm{~h}$ after saline. There was no change in the CD14 expression on peripheral blood granulocytes before and $18 \mathrm{~h}$ after segmental allergen provocation.

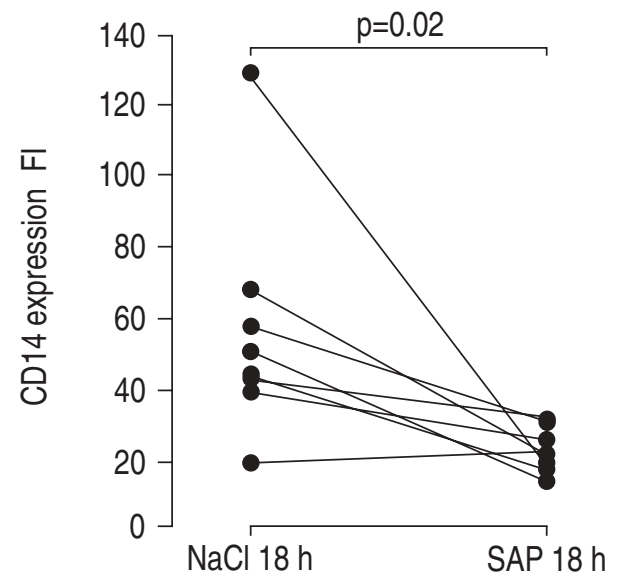

Fig. 1. - Expression of CD14 on granulocytes in bronchoalveolar lavage $18 \mathrm{~h}$ after endobronchial saline challenge $(\mathrm{NaCl} 18 \mathrm{~h})$ and $18 \mathrm{~h}$ following segmental allergen provocation (SAP $18 \mathrm{~h}$ ). FI: fluorescence intensity.

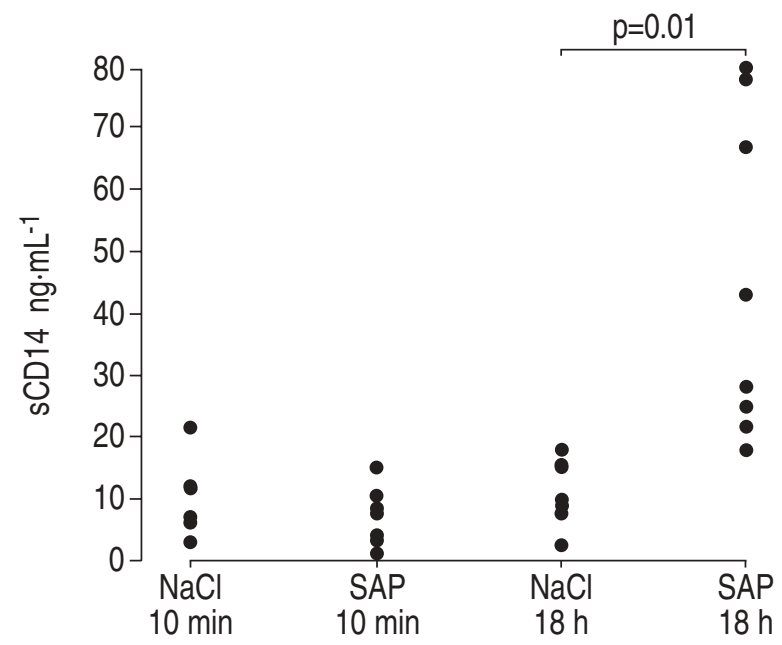

Fig. 2. - Concentrations of soluble CD14 (sCD14) in bronchoalveolar lavage $10 \mathrm{~min}(\mathrm{NaCl} 10 \mathrm{~min})$ and $18 \mathrm{~h}(\mathrm{NaCl} 18 \mathrm{~h})$ after endobronchial saline challenge as well as $10 \mathrm{~min}$ (SAP $10 \mathrm{~min}$ ) and $18 \mathrm{~h}$ (SAP $18 \mathrm{~h}$ ) following segmental allergen provocation.

\section{Soluble CD14}

A significantly higher concentration of sCD14 was observed in the allergen challenged segment $18 \mathrm{~h}$ after allergen instillation $\left(45.1 \pm 26.1 \mathrm{ng} \cdot \mathrm{mL}^{-1}\right)$ as compared to the control segment lavaged $18 \mathrm{~h}$ after saline challenge (10.6 \pm $\left.5.2 \mathrm{ng} \cdot \mathrm{mL}^{-1}, \mathrm{p}=0.01\right)$ while $\mathrm{sCD} 14$ concentrations in the segments lavaged $10 \mathrm{~min}$ after saline $\left(10.2 \pm 6.5 \mathrm{ng} \cdot \mathrm{mL}^{-1}\right)$ and $10 \mathrm{~min}$ after allergen challenge $\left(6.3 \pm 5.0 \mathrm{ng} \cdot \mathrm{mL}^{-1}\right)$ were similar (fig. 2).

\section{Concentrations of IFN- $\gamma, T N F-\alpha, I L-4, I L-5$ and $I L-13$}

IFN- $\gamma$ concentrations measured at $10 \mathrm{~min}(45.0 \pm 62.8$ $\left.\mathrm{pg} \cdot \mathrm{mL}^{-1}\right)$ and $18 \mathrm{~h}\left(64.8 \pm 66.5 \mathrm{pg} \cdot \mathrm{mL}^{-1}\right)$ after allergen challenge and $18 \mathrm{~h}\left(64.0 \pm 146.0 \mathrm{pg} \cdot \mathrm{mL}^{-1}\right)$ after saline instillation were not significantly different. In contrast, the
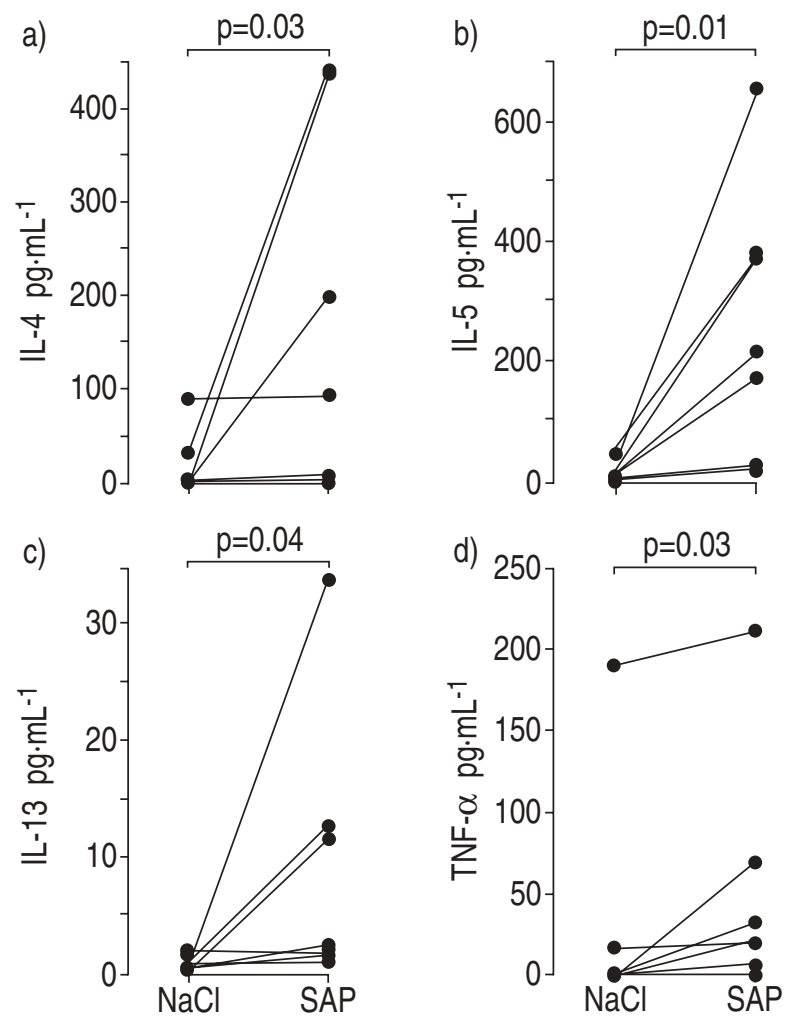

Fig 3 - Concentrations of: a) interleukin (IL)-4; b) IL-5; c) IL-13; and d) tumour necrosis factor (TNF)- $\alpha$ in bronchoalveolar lavage $18 \mathrm{~h}$ $(\mathrm{NaCl})$ following endobronchial saline challenge and $18 \mathrm{~h}(\mathrm{SAP})$ after segmental allergen provocation. 


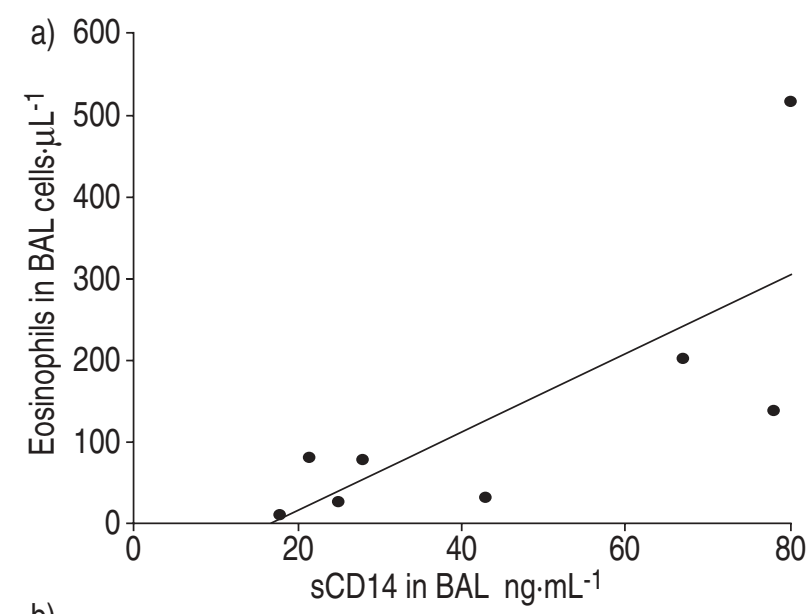

to a region in chromosome 5 encoding for several cytokines and receptors related to the pathogenesis of asthma $[27,28]$. CD14 mediated binding of LPS and lipopolysaccharide binding protein (LBP) can induce macrophage activation, which has been described as a feature of bronchial asthma [21]. Since inhalation of LPS in patients with asthma can increase bronchial hyperreactivity [29] and domestic endotoxin exposure has been related to asthma severity [30], both CD14 expression and soluble CD14 concentrations could be relevant to the pathogenesis of bronchial asthma.

In this study, using the model of SAP, we observed a substantial increase in the concentration of sCD14 in BAL fluid of allergen challenged segments as compared to sham challenges. Despite a large accompanying increase in macrophages, no significant change in CD14 cell surface expression was observed in this cell population as compared to controls. To our knowledge this is the first report of an elevated CD14 expression on granulocytes (eosinophils and neutrophils) in BAL as compared to CD14 expression on peripheral blood granulocytes in patients with asthma. A number of cytokines present in BAL fluid following segmental allergen provocation [20, 31] can activate eosinophils as well as neutrophils. Interestingly, however, CD14 expression in this cell population decreased following SAP despite a large increase in eosinophil and neutrophil numbers $18 \mathrm{~h}$ after allergen provocation. This observed reduction in CD14 expression was accompanied by elevated concentrations of sCD14 $18 \mathrm{~h}$ following SAP.

Our study extends previous observations of elevated concentrations of SCD14 in various other pulmonary diseases $[9,15]$. In fact, mean sCD14 concentrations in BAL of allergic asthmatics $18 \mathrm{~h}$ after segmental allergen provocation were similar to those reported for active sarcoidosis [9] and slightly higher than in patients with tuberculosis $[9,15]$.

Elevated levels of sCD14 following allergen provocation have been detected recently [19]. The authors of this study observed an increase of sCD14 as well as LPS $24 \mathrm{~h}$ after SAP. In the study of DUBIN et al. [19], low levels of LPS in BAL fluid were insufficient to stimulate cytokine release from macrophages. Following SAP, the increase in SCD14 resulted in functional activity of the LBP-LPS complex, which can bind to sCD14 with subsequent release of cytokines from macrophages [19]. The authors were unable to relate the observed increase in SCD14 to the expression of CD14 on inflammatory cells in BAL fluid obtained $24 \mathrm{~h}$ after SAP. Similar to our observation of a correlation between eosinophils and sCD14 levels, a close correlation between the concentration of LBP and the percentage of eosinophils recovered in BAL fluid was observed.

Activated macrophages have been implicated as a source of sCD14 [10]. However, DUBIN et al. [19] rejected macrophages as the source of sCD14 and hypothesized that the observed increase in SCD14 in their study must be caused by plasma extravasation following allergen provocation. In contrast to their study, we have used two different timepoints for BAL fluid collection following allergen provocation. Our observations of unchanged sCD14 levels in BAL fluid $10 \mathrm{~min}$ after allergen provocation strongly suggest that the observed increase in sCD14 must take place between $10 \mathrm{~min}$ and $18 \mathrm{~h}$ following allergen provocation.

D14, a myelomonocytic differentiation antigen, has been described on a variety of cells implicated in the pathogenesis of bronchial asthma. The gene for CD14 maps 
This questions the assumption of DUBIN et al. [19] that sCD14 is derived exclusively from the circulation. Ten minutes after allergen provocation a marked swelling of the bronchial mucosa could be observed through the bronchoscope. This reaction has been attributed to increased vascular permeability [32] allowing immediate exudation of proteins with a molecular mass as large as $340 \mathrm{kDa}$ [32]. Albumin, with a molecular mass of $69 \mathrm{kDa}$, which is slightly larger than that of sCD14 (48-54 kDa), is already present at baseline conditions and increases significantly immediately after allergen challenge [33]. As yet, there is no evidence suggesting that extravasation of sCD14 is regulated differently to other plasma proteins. Therefore, our findings of unchanged sCD14 levels 10 min after segmental allergen challenge but significantly increased concentrations $18 \mathrm{~h}$ after allergen provocation would be compatible with the hypothesis that sCD14 could also be produced locally in the bronchoalveolar compartment.

CD14 has been described as a glycosylphosphatidylinositol-anchored protein in neutrophils [34]. To our knowledge, this is the first report addressing the contribution of granulocytes to the local sCD14 pool. Although CD14 expression on granulocytes was significantly lower compared to macrophages, we found a markedly upregulated expression of CD14 on endobronchial granulocytes compared to granulocytes from peripheral blood of the same patients prior to allergen provocation. CD14 expression in this cell population decreased significantly $18 \mathrm{~h}$ after segmental allergen provocation. One of the possible explanations for this observation could be shedding of CD14 from the surface of these cells.

Endotoxin-activity has been reported in allergen-extracts used for SAP [35]. Therefore, we cannot fully exclude the contribution of exogenous endotoxins to a number of features observed following segmental or inhaled allergen provocation such as increased IL- 2 and TNF- $\alpha$ concentrations, as well as neutrophil infiltration [20, 36]. However, since in vivo administration of LPS induces a sharp increase in serum TNF- $\alpha$ at 90 min which returns to baseline within $4 \mathrm{~h} \mathrm{[37]} \mathrm{it} \mathrm{appears} \mathrm{unlikely} \mathrm{that} \mathrm{the} \mathrm{observed}$ effects of our study are solely related to endotoxin.

IL-13 which is produced locally following SAP [31] has been shown to downregulate CD14 messenger ribonucleic acid (mRNA) in vitro [13]. This is in contrast to our observation of a correlation between IL-13 and SCD14 concentrations in BAL fluid $18 \mathrm{~h}$ after segmental provocation, challenging the in vivo relevance of in vitro data [13].

In conclusion, our study is the first to provide evidence about the endobronchial regulation of soluble CD14 over time following segmental allergen provocation. Our results suggest that in addition to macrophages, granulocytes are a possible source of this soluble surface marker which can be measured in markedly elevated concentrations $18 \mathrm{~h}$ but not 10 min after segmental allergen challenge. Interleukin-13, which has been implicated in the regulation of CD14 expression in vitro [13], might also be related to soluble CD14 levels in vivo. The observation of elevated soluble CD14 levels as a feature of the inflammatory response following segmental allergen provocation and their relationship to inflammatory cells implicated in the pathogenesis of asthma suggests that CD14-mediated mechanisms could augment allergic inflammation in the absence of allergen.
Acknowledgements: The authors wish to thank S. Bock for her expert technical assistance and U.F. Senge for critical reading of the manuscript.

\section{References}

1. Goyert SM, Ferrero E, Rettig WJ, Yenamandra AK, Obata F, Le Beau MM. The CD14 monocyte differentiation antigen maps to a region encoding growth factors and receptors. Science 1988; 239: 497-500.

2. Ziegler-Heitbrock HW, Ulevitch RJ. CD14: cell surface receptor and differentiation marker. Immunol Today 1993; 14: 121-125.

3. Wright SD, Ramos RA, Tobias PS, Ulevitch RJ, Mathison JC. CD14, a receptor for complexes of lipopolysaccharide (LPS) and LPS binding protein. Science 1990; 249: 14311433.

4. Dentener MA, Bazil V, Von Asmuth EJ, Ceska M, Buurman WA. Involvement of CD14 in lipopolysaccharide-induced tumor necrosis factor-alpha, IL-6 and IL-8 release by human monocytes and alveolar macrophages. J Immunol 1993; 150: 2885-2891.

5. Lauener RP, Goyert SM, Geha RS, Vercelli D. Interleukin 4 down-regulates the expression of CD14 in normal human monocytes. Eur J Immunol 1990; 20: 2375-2381.

6. Ruppert J, Friedrichs D, Xu H, Peters JH. IL-4 decreases the expression of the monocyte differentiation marker CD14, paralleled by an increasing accessory potency. Immunobiology 1991; 182: 449-464.

7. Firestein GS, Zvaifler NJ. Down regulation of human monocyte differentiation antigens by interferon gamma. Cell Immunol 1987; 104: 343-354.

8. Ishizuka T, Hirata I, Adachi M, et al. Effects of interferon-gamma on cell differentiation and cytokine production of a human monoblast cell line, U937. Inflammation 1995; 19: 627-636.

9. Striz I, Zheng L, Wang YM, Pokorna H, Bauer PC, Costabel U. Soluble CD14 is increased in bronchoalveolar lavage of active sarcoidosis and correlates with alveolar macrophage membrane-bound CD14. Am J Respir Crit Care Med 1995; 151: 544-547.

10. Landmann R, Fisscher AK, Obrecht JP. Interferongamma and interleukin-4 down-regulate soluble CD14 release in human monocytes and macrophages. J Leukoc Biol 1992; 52: 323-330.

11. Bufler P, Stiegler G, Schuchmann M, et al. Soluble lipopolysaccharide receptor (CD14) is released via two different mechanisms from human monocytes and CD14 transfectants. Eur J Immunol 1995; 25: 604-610.

12. Schutt C, Schilling T, Grunwald U, Schonfeld W, Kruger C. Endotoxin-neutralizing capacity of soluble CD14. Res Immunol 1992; 143: 71-78.

13. Cosentino G, Soprana E, Thienes CP, Siccardi AG, Viale G, Vercelli D. IL-13 down-regulates CD14 expression and TNF-alpha secretion in normal human monocytes. $J$ Immunol 1995; 155: 3145-3151.

14. Labeta MO, Durieux JJ, Fernandez N, Herrmann R, Ferrara $\mathrm{P}$. Release from a human monocyte-like cell line of two different soluble forms of the lipopolysaccharide receptor, CD14. Eur J Immunol 1993; 23: 2144-2151.

15. Hoheisel G, Zheng L, Teschler H, Striz I, Costabel U. Increased soluble CD14 levels in BAL fluid in pulmonary tuberculosis. Chest 1995; 108: 1614-1616.

16. Martin TR, Rubenfeld G, Steinberg KP, et al. Endotoxin, endotoxin-binding protein, and soluble CD14 are present 
in bronchoalveolar lavage fluid of patients with adult respiratory distress syndrome. Chest 1994; 105: 55S-56S.

17. Pforte A, Schiessler A, Gais P, et al. Increased expression of the monocyte differentiation antigen CD14 in extrinsic allergic alveolitis. Monaldi Arch Chest Dis 1993; 48: 607-612.

18. Pforte A, Schiessler A, Gais P, et al. Expression of CD14 correlates with lung function impairment in pulmonary sarcoidosis. Chest 1994; 105: 349-354.

19. Dubin W, Martin TR, Swoveland P, et al. Bronchoalveolar lavage, segmental allergen challenge, macrophage, interleukin-6, endothelial cell, asthma and endotoxinlipopolysaccharide binding protein and soluble CD14 in bronchoalveolar compartment. Am J Physiol Lung Cell Mol Physiol 1996; 14: L736-L744.

20. Virchow JC Jr, Walker C, Hafner D, et al. T-cells and cytokines in bronchoalveolar lavage fluid after segmental allergen provocation in atopic asthma. Am J Respir Crit Care Med 1995; 151: 960-968.

21. Chanez P, Bousquet J, Couret I, et al. Increased numbers of hypodense alveolar macrophages in patients with bronchial asthma. Am Rev Respir Dis 1991; 144: 923-930.

22. Anonymous. International consensus report on diagnosis and treatment of asthma. National Heart, Lung and Blood Institute, National Institutes of Health, Bethesda, Maryland, USA. Eur Respir J 1992; 5: 601-641.

23. Cockcroft DW, Killian DN, Mellon JJ, Hargreave FE. Bronchial reactivity to inhaled histamine: a method and clinical survey. Clin Allergy 1977; 7: 235-243.

24. Ruhle KH, Matthys H. Kritische Auswahl von Sollwerten für ein Computerprogramm zur Routinlungenfunktionsdiagnostik. Pneumonologie 1976; 153: 223-233.

25. Warren HS, Glennon ML, Wainwright N, et al. Binding and neutralization of endotoxin by Limulus antilipopolysaccharide factor. Infect Immun 1992; 60: 2506-2513.

26. Luttmann W, Herzog V, Virchow JC Jr, Matthys H, Thierauch KH, Kroegel C. Prostacyclin modulates granulocyte/macrophage colony-stimulating factor release by human blood mononuclear cells. Pulmonary Pharmacology 1996; 9: 43-48.
27. Zhang DE, Hetherington CJ, Tan S, et al. Sp1 is a critical factor for the monocytic specific expression of human CD14. J Biol Chem 1994; 269: 11425-11434.

28. Postma DS, Bleecker ER, Amelung PJ, et al. Genetic susceptibility to asthma, bronchial hyperresponsiveness coinherited with a major gene for atopy. $N$ Engl J Med 1995; 333: 894-900.

29. Michel O, Duchateau J, Sergysels R. Effect of inhaled endotoxin on bronchial reactivity in asthmatic and normal subjects. J Appl Physiol 1989; 66: 1059-1064.

30. Michel O, Ginanni R, Duchateau J, Vertongen F, Le Bon B, Sergysels R. Domestic endotoxin exposure and clinical severity of asthma. Clin Exp Allergy 1991; 21: 441-448.

31. Kroegel C, Julius P, Matthys H, Virchow JC Jr, Luttmann W. Endobronchial secretion of interleukin-13 following local allergen challenge in atopic asthma: relationship to interleukin-4 and eosinophil counts. Eur Respir J 1996; 9: 899-904.

32. Salomonsson P, Gronneberg R, Gilljam H, et al. Bronchial exudation of bulk plasma at allergen challenge in allergic asthma. Am Rev Respir Dis 1992; 146: 1535-1542.

33. Fick RB Jr, Metzger WJ, Richerson HB, et al. Increased bronchovascular permeability after allergen exposure in sensitive asthmatics. J Appl Physiol 1987; 63: 1147-1155.

34. Maciejewski JP, Young NS, Yu M, Anderson SM, Sloand EM. Analysis of the expression of glycosylphosphatidylinositol anchored proteins on platelets from patients with paroxysmal nocturnal hemoglobinuria. Thrombosis Research 1996; 83: 433-447.

35. Hunt LW, Gleich GJ, Ohnishi T, et al. Endotoxin contamination causes neutrophilia following pulmonary allergen challenge. Am J Respir Crit Care Med 1994; 149: 14711475.

36. Robinson DS, Hamid Q, Ying S, et al. Predominant TH2-like bronchoalveolar T-lymphocyte population in atopic asthma. N Engl J Med 1992; 326: 298-304.

37. Michie HR, Manogue KR, Spriggs DR, et al. Detection of circulating tumor necrosis factor after endotoxin administration. N Engl J Med 1988; 318: 1481-1486. 